6

\title{
Evaluation of Imperviousness Impacts in Large, Developing Watersheds
}

\author{
Michael A. Gregory, John A. Aldrich, Amy L. Holtshouse and \\ Kyle Dreyfuss-Wells
}

Land use changes and development practices that increase imperviousness can significantly alter and disrupt the natural and water resources within watersheds. Evaluating impacts of imperviousness in large watersheds can be a labor-intensive and time-consuming task and there is a need for simplified, planning-level methods that are easy to use and apply. There is also a need to educate and communicate results at the community level. This chapter presents methods for estimating the increase in impervious cover from development and for quantifying the resulting impact of various development practices on imperviousness in large watersheds. A case study in northeast Ohio demonstrates the approaches and methodologies.

\subsection{Introduction}

Urbanization introduces impermeable surfaces to the natural landscape; as land is developed for urban uses, impervious materials replace the natural land cover. The resulting impact on runoff is well understood: runoff is directly proportional to imperviousness. Other impacts of imperviousness are not as obvious. Land use changes and development practices can increase imperviousness and significantly alter and disrupt the watershed by

Gregory, M., J. Aldrich, A. Holtshouse and K. Dreyfuss-Wells. 2006. "Evaluation of Imperviousness Impacts in Large, Developing Watersheds." Journal of Water Management Modeling R225-06. doi: 10.14796/JWMM.R225-06.

(C) CHI 2006 www.chijournal.org ISSN: 2292-6062 (Formerly in Intelligent Modeling of Urban Water Systems. ISBN: 0-9736716-2-9) 
increasing flooding frequency, reducing groundwater recharge and baseflow in streams, threatening stream stability, terrestrial and aquatic habitats, and increasing pollutant loads to surface and groundwater resources.

Increased impervious surface is a consequence of development and can serve as a surrogate indicator of watershed degradation due to urbanization. However, there is not much literature documenting quantitative relationships between land use policy or development types and their resulting impact on hydrology or other environmental factors.

Land use planning and development practices are the means by which imperviousness is allowed to affect land surfaces. Even modest changes to municipal land development regulations could yield significant reductions in imperviousness (Stone, 2004). It is therefore critical to understand how land use planning decisions affect imperviousness as well as how increased imperviousness affects watershed hydrology, flooding, stream stability, and attainment of water quality standards.

An evaluation of the impact of imperviousness resulting from development practices must be sufficient to support a range of professionals (e.g. engineers, planners, and land use policy makers) in the designs and site plans that introduce impervious cover into developments as well as in the zoning and policy tools that are intended to regulate and control impervious cover. In addition, the interrelationship of development and imperviousness impacts must be presented and communicated meaningfully to public officials, residents, and other stakeholders for land development to advance in an environmentally sound fashion. By understanding the impact of potential land use changes on the flooding, erosion, and water quality problems of the watershed, it is assumed that better land use planning and management decisions can be made.

This chapter is focused on issues that are more applicable to large watersheds, particularly those involving many local government jurisdictions. Large scale watershed models simulate the hydrologic response of land surfaces on a catchment basis, such that several hundred properties could be lumped together into a single hydrologic unit. Land use, on the other hand, is regulated at the lot or parcel level, such that adjacent properties could feature quite diverse zoning and hence imperviousness characteristics. The challenge lies in relating imperviousness to the zoning and development status of individual parcels.

In large watersheds with many communities, the evaluation of imperviousness impacts is therefore labor-intensive and time-consuming, necessitating the use of Geographic Information Systems (GIS) and other digital analysis and processing tools. 
As a result, there is a need for simplified, planning-level methods that can link various development practices with the resulting impacts on hydrology, as well as educate and communicate results to a non-technical audience. The objectives of this chapter include discussion of the following topics:

- overview of imperviousness and its impacts on water quantity and quality;

- land use and development policies that affect imperviousness; and

- development practices and constructed facilities (e.g. Best Management Practices, or BMPs) that control or minimize the impacts of imperviousness.

In addition, a case study for a large watershed in northeast Ohio is used to demonstrate the approaches and methodologies presented, as well as to highlight the application of planning-level methods for:

- estimating increases in impervious cover from land use changes due to projected development, and

- quantitatively assessing the effectiveness of development practices to control imperviousness or to control the resulting impacts of increased impervious cover.

\subsection{Impervious Surface Characteristics}

In this section the various physical characteristics of impervious area are described along with a summary of popular methods for measuring imperviousness.

\subsubsection{Definitions}

For the purposes of this discussion, the following definitions are used:

- Impervious Cover: Any land surface that has been compacted or is covered with a layer of material such that it substantially reduces or prevents the infiltration of stormwater runoff into the ground.

- Imperviousness: The percentage of impervious cover within a given area of land.

In general terms, imperviousness is a measure of the urbanization demands of people and their transportation needs. It is the hallmark of development and the antithesis of undisturbed natural landscapes. 
Impervious surfaces may include paved roadways, parking areas, driveways, sidewalks, building rooftops, and similar structures. It is most visible in heavily industrialized and retail commercial areas. Although less pervasive, imperviousness is abundant in residential neighborhoods in such structures as garages, patios, and sheds. Heavily compacted soils, gravel areas, and waterbodies can also have impervious characteristics.

Imperviousness values range from 0 to $100 \%$. Natural areas with welldrained permeable soils are represented at the lower end of the range, and urban areas completely covered in impervious materials are at the upper end.

\subsubsection{Impervious Area Components}

From a hydraulic standpoint, impervious cover can be classified into two distinct categories, depending on how runoff from impervious areas is discharged to the stormwater management system. The stormwater management system is the series of conveyance channels and conduits (e.g. rivers, streams, canals, ditches, culverts, pipes, streets, swales) and storage facilities (e.g. lakes, ponds, detention/retention facilities).

The two components of impervious area are:

- Directly connected impervious area (DCIA): This is the portion of the total impervious area that enters the stormwater management system by means of a direct hydraulic connection. Examples of DCIA include impervious areas that are directly tributary to catchbasins or other inlet types, rooftop drains, and gutters.

- Non-directly connected impervious area (non-DCIA): This is the portion that discharges onto pervious surface areas and is therefore delayed in its entry to the stormwater management system. Examples of non-DCIA include building rooftop drains that discharge onto lawns, and roadway or parking areas whose runoff is directed to vegetated filter strips or swales.

For most storms (i.e. small volume, low intensity rainfall events), it is the DCIA portion of impervious areas that contributes runoff. For larger storms, the entire impervious area, both DCIA and non-DCIA, contributes runoff to the stormwater management system. For the rare events with large volume and high intensity rainfall (e.g. events exceeding a $25 \mathrm{y}$ return period), even the pervious areas contribute runoff.

Relationships between DCIA and total impervious area have been suggested by researchers. Based on samples from a highly urbanized area in 
Denver, the empirical relationship shown in Equation 6.1 was defined (Alley and Veenhuis, 1983):

where:

$$
D C I A=0.15 \times I^{1.41}
$$

DCIA $=$ the DCIA portion as defined above, and

$\mathrm{I}=$ the total impervious area.

It should be noted that impervious area values, such as those used to develop Equation 6.1 can vary greatly according to the methods used to estimate imperviousness (Lee and Heaney, 2003).

\subsubsection{Estimation Techniques}

Imperviousness is not necessarily a physical property that can be accurately measured on an absolute scale over a large area. Even for a given material type, imperviousness varies by the installation method, loading history, and other chemical and biological processes. It is however a useful designation of surface material type from both a regulatory and watershed analysis perspective and can be estimated by a variety of methods.

Estimating imperviousness for large watersheds requires intensive data and computational efforts, necessitating the use of GIS tools. There are a variety of GIS and mapping tools that can be used to estimate impervious area (Stocker, 1998; Lee and Heaney, 2003).

Common measurement methods are described below. Regardless of the method or combination of methods used to estimate imperviousness, some form of field verification will be necessary. In addition, field verification is the only reliable way to estimate the DCIA portion.

\section{Existing Data Conversion}

The easiest yet least accurate way to identify land cover is to digitize existing maps or convert existing digital files. A significant amount of judgment may be required to interpret the zoning maps, particularly in large watersheds where local zoning codes for individual communities need to be assigned to representative, watershed-wide, land use categories. In addition, accuracy and mapping standards likely vary between communities, and the resulting product will be limited to the format, quality, and scale of the source data. 
If zoning maps are the only source of data (i.e., existing data is not augmented by the other measurement techniques described below), then gross assumptions concerning imperviousness must be made. For example, all parcels within a low-density residential zone must be assigned the same imperviousness value, which is not reasonable.

Survey

Traditional ground survey offers the most accurate means for measuring impervious areas. It is also the most expensive and time-consuming method. Global Positioning Systems (GPS) offer an accurate, cost-effective, and practical method to augment existing data sources in large watersheds.

\section{Aerial Photograph Interpretation}

Imperviousness estimates for large watersheds are typically performed by interpreting land cover characteristics from digital aerial orthophotographs. The interpretation is improved when used in conjunction with digital road right-of-way and building outline or "footprint" data. Special stereo photogrammetry methods and equipment can greatly reduce the inherent distortion in the air photos caused by the camera lens, radial optics, and ground terrain.

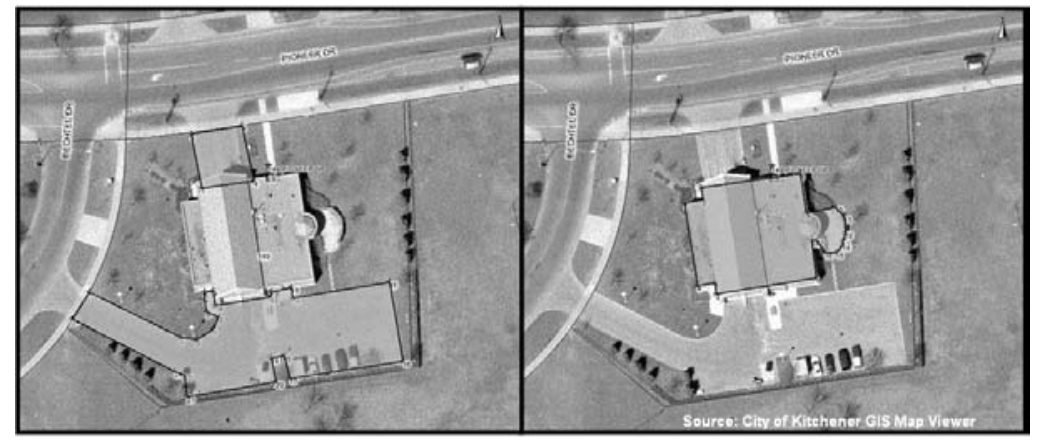

Figure 6.1 Aerial photo interpretation of imperviousness (paved areas have been delineated in the left photo, building area on the right).

Figure 6.1 shows two photographs of a 1-acre $\left(4,047 \mathrm{~m}^{2}\right)$ parcel. Paved impervious areas were interpreted in the left photograph and delineated by a black line. Paved areas account for a total area of 0.29 acres $\left(1,183 \mathrm{~m}^{2}\right)$. The building roof area was interpreted in the right photograph and accounts for a 
total area of 0.17 acres $\left(689 \mathrm{~m}^{2}\right)$. The total imperviousness of the parcel is therefore $46 \%$.

\section{Satellite Remote Sensing}

Computer-assisted interpretation of satellite imagery is also applicable for use in large watersheds. Image pixel size is a limiting factor, and in urban areas a pixel size of $10 \mathrm{~m}$ or more could easily lead to misinterpretation of impervious surfaces. In addition, the accuracy with which pixels are classified into land cover categories depends on the reflection characteristics of the surface, cloud and vegetation cover, ground truth and other data quality control procedures.

\subsection{Imperviousness Impacts}

In this section, the impacts of increased imperviousness on water quantity and quality are described.

New development is more than just adding impervious area. Urbanization often requires clearing of vegetation and surface soil layers, to be replaced with graded and compacted fill and topsoil. In addition, natural drainage patterns are altered and the conveyance, storage, and treatment functions and features are replaced with engineered systems and facilities.

Increased imperviousness and the related construction activities associated with urban development can result in a combination of adverse impacts in developing watersheds. Impacts, such as increased runoff, are intuitive. Other environmental consequences in nearby lands and waterbodies may not be as obvious. These impacts are often cumulative, affecting fish and wildlife in various ways, and therefore pose potentially significant monetary and ecological costs to citizens and local governments within a watershed. The various impacts are summarized below and described in detail by others (Schueler, 2003; U.S. Environmental Protection Agency, 1997).

\subsubsection{Water Quantity}

One of the most noticeable impacts of increased imperviousness is the increase in flooding magnitude and frequency.

Urbanization interrupts the hydrologic cycle. In some cases, despite wellintentioned engineering designs, new facilities may have high maintenance 
requirements or maintenance is otherwise ignored, with consequences beyond just poor hydraulic performance. In addition to new impervious surfaces that reduce the area of land available for infiltration, development can affect all natural runoff pathways, including:

- overland flow patterns, by revising the existing site grading and placement of inlets (note this even changes the character of pervious areas, due to the use of imported topsoil, non-native vegetation, and lot grading which is intended to direct water away from buildings);

- conveyance properties, by adding new underground piped collection systems or channelization of streams; and

- storage properties, by adding fill to floodplain storage areas or replacing existing retention features with new detention facilities designed for specific design events rather than a range of hydrologic conditions.

Imperviousness directly affects the amount of runoff generated. An increase in impervious area results in an almost linearly proportional increase in runoff volume. Not only does the amount of runoff increase, but the timing of runoff is quicker due to the smoother surfaces and lower roughness factors. Other development factors compound the problem by delivering the runoff more quickly and efficiently, from a hydraulic standpoint, to receiving waters. Another perspective is to view the composite runoff response of DCIA as having two equally important components: runoff delivery as the "DC" portion representing the engineered drainage system, and runoff generation as the "IA" portion representing imperviousness.

The combined effect of this response on the receiving water is a quicker timing of the peak or "flashiness" in the stream during rainfall events. Other in-stream hydrologic impacts may include higher peak flow rate, depth, and velocity. In addition, the duration that flow depths or velocities exceed certain thresholds may increase (e.g. bank-full or road flooding depths, maximum permissible erosive or fish migration velocities).

The opposite effect can occur below the ground surface, since increased imperviousness can reduce the amount of water available for groundwater recharge. Streams that are dependent on groundwater flow contributions are especially vulnerable to the lower water table that results when impervious surfaces cover areas where water naturally infiltrates, resulting in reduced dry weather baseflow. 


\subsubsection{Water Quality}

Similar to water quantity impacts, urbanization generates new pollutants and urban drainage systems accelerate the delivery of pollutants to receiving waters. Increased imperviousness, by association, therefore leads to poorer water quality and an increase in pollution threats to water resources.

There are a host of common urban pollutants including pesticides, fertilizers, bacteria, nutrients such as phosphorus and nitrogen, heavy metals, and other toxic contaminants. The sources and pathways of these pollutants are also numerous including business and homeowner activities, vehicles, air pollutants, de-icing chemicals, litter, wastewater facilities, animal wastes.

Impervious areas provide a suitable surface for these pollutants to accumulate between rainfall events and a pollutant source for delivery to receiving waters during wet weather. In-stream impacts can also be affected (e.g. increased nutrients can lead to algae blooms, which can block sunlight, deplete oxygen, inhibit the growth of other aquatic plants, and adversely affect recreational activities).

\subsubsection{Stream Stability}

The impacts of increased imperviousness can alter the form and function of streams, reducing their stability.

The increased runoff amount and rate can result in increased stream channel and bank erosion, incising of the stream channel, altered meander pattern of the channel, increases in channel width, etc. In addition to the increased sediment loads and concentrations generated from urban areas, the increased erosion within the stream will lead to increased sedimentation elsewhere within the receiving water.

Another impact of development in the riparian corridor along streams is the removal of trees, shrubs, grasses, and vegetation which naturally trap silt and sediment thereby stabilizing erodible stream banks. More frequent stream blockage can result with development features such as new culvert or bridge crossings, in-stream dams or weirs, and other utility crossings.

\subsubsection{Terrestrial and Aquatic Habitat}

Research studies have identified a correlation between imperviousness and stream ecology, including degraded terrestrial and aquatic ecosystems, and loss of biological diversity and habitat. 
The research suggests that thresholds of stream quality exist, the first at about $10 \%$ imperviousness, below which the highest quality ecological indicators are present, and above which the biological diversity shifts toward pollution-tolerant species (Schueler, 2003). A second threshold appears at about 25\% imperviousness, where most ecological indicators are poor (e.g. poor aquatic diversity, poor water quality, and low habitat scores).

All of the previously noted impacts may be cumulative and severely stress aquatic species, damaging plant, fish, and invertebrate habitat. Higher runoff flows and lower baseflows significantly alter these habitats. Increasingly deposited sediments can smother habitat, and the drastic alteration of pools, riffles, and sandbar sequences as well as scouring of bottom substrates can further stress aquatic organisms, resulting in loss of fish production and changes in species diversity. These impacts can easily be transferred to the habitats of waterfowl and other species of animals and plants.

In addition, terrestrial habitat is lost when the natural riparian vegetation is removed or severely impacted. Construction of impervious surfaces reduces the area of land that can support forest or other types of woodland vegetation, thereby fragmenting, isolating, or displacing a great number of terrestrial species.

\subsubsection{Temperature}

Increased temperature is another consequence of urbanization and its resulting increased imperviousness.

Impervious surfaces generally have a much higher thermal capacity than surfaces in a natural landscape, resulting in an urban heat island effect. Impervious surfaces, particularly dark colored surfaces (e.g. rooftops, parking lots, and roadways), have the capacity to absorb more heat during the day. Removal of vegetative cover, which provides natural heat attenuation, also compounds the problem. Resulting summer daytime air temperatures can be 6 to $8{ }^{\circ} \mathrm{F}$ hotter in a city than in surrounding areas (Rosenfeld et al., 1997). A further consequence is the increased energy consumption of cooling equipment, which in turn, increases the demand on power generating stations.

The runoff from heated impervious surfaces results in significant increases to the temperature of receiving waters, posing an immediate threat to aquatic species and their habitat. 


\subsection{Land Use Planning and Development}

In order to evaluate the impact of various land use development scenarios on imperviousness, a link is required that relates impervious cover to land use characteristics. This section gives an overview of the planning and regulation of land use as well as the development processes that affect imperviousness.

The word "development" is used in a broad context in this chapter, denoting both the planning and regulatory processes that affect designated land uses as well as new construction, redevelopment, or infill within existing parcels. This section deals with the planning aspects and the following section elaborates on the structural components of development.

In communities that are faced with development and redevelopment pressures, it is critical that public officials and residents understand the impact of increased imperviousness on watershed hydrology, flooding, stream stability, and attainment of water quality standards. To communicate the results of their technical analyses, it is equally important for engineers to understand the fundamentals of land use planning and appreciate the basic development processes.

\subsubsection{Land Use Regulation}

Land use is another wide-ranging term. It is more than just the way we plan the physical layout of parcels of land in a community. The land use of a given parcel can be categorized in many ways, including:

- physical activity that is permitted to take place;

- economic function of the establishment(s) on the premises;

- tax assessment class of the property;

- type of structures or buildings present;

- ownership rights (e.g. public, private, or easements);

- development status of the parcel (e.g. not developable, vacant, or built-out); and

- type of land cover. For the purposes of this chapter, the land cover type refers to its hydrologic response characteristics according to imperviousness and is described in detail in Section 6.6.

Land use planning and the resulting policies and regulations are highly site specific. This may be necessary to reflect the community's unique identity, natural and cultural resources, which are also influenced by local economic and political forces. 
Land use planning policies of local governments follow the rules and regulations set out by the appropriate state or provincial policies. The local policies are embodied in a document which provides a framework for guiding future land use and development within a community or regional context (e.g. an Official Plan in Canada or a Comprehensive Plan in the U.S.).

There has been a general shift recently in local land use policies that is guiding community land use decisions towards environmental sustainability, rather than just strictly quality of life and political/economic considerations. Sustainability implies land use planning practices that create and maintain efficient infrastructure, foster a sense of community, and preserve natural resources.

The focus of this chapter is on land use and development at the local level of government. Locally, land use can be regulated in several ways, including:

- legislatively (e.g. through policies, ordinances, codes, regulations, etc.);

- quasi-judicially (e.g. through variances, conditional uses, appeals, etc.); and

- administratively (e.g. through site plan reviews of land use development applications, permits, inspection, enforcement, coordination with neighboring jurisdictions or other governmental agencies, etc.).

\subsubsection{Imperviousness Relationships}

This section highlights how imperviousness is associated with local land use regulations, particularly in the legislative controls described above. Imperviousness is a very practical basis for land use planning tools related to natural and water resources protection, since it is measurable, easily recognized and understood by the general public (Gibbons, 1998).

\section{Zoning Ordinance/By-Law}

A zoning ordinance is the corresponding companion document to the Comprehensive Plan. In Canada the equivalent is a zoning by-law, which corresponds to the community's Official Plan. A zoning ordinance codifies the use and type of development of all land within a jurisdiction, and designates the local regulations governing the permitted use, configuration, spacing, and size of buildings and lots within a distinct land use zone. 
The main purpose of a zoning ordinance is to ensure that new development is built according to the overall Comprehensive/Official Plan and represents a balance between individual property rights and the general welfare, health/safety, and orderly living environment of the public. The ordinance is also a mechanism for separating conflicting land uses and preserving valued natural and environmental features.

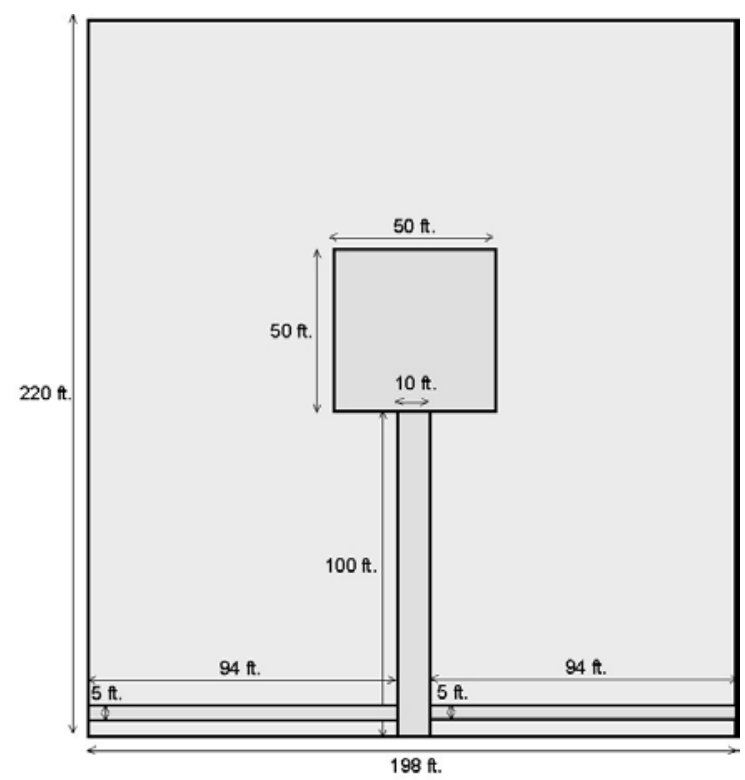

Figure 6.2 Conceptual sketch of a 1-acre residential parcel.

Figure 6.2 shows a sketch of a 1-acre (0.4 ha) residential parcel and is used to relate zoning ordinance features with imperviousness characteristics, including:

- Lot size. The density of development is specified in the zoning ordinance by the allowable lot size.

- Setback. The front yard setback is the distance from the street curb or right-of-way to the building structure. This dimension directly correlates to the driveway length (i.e., larger setbacks result in longer driveways). The setback distance in the sketch is $100 \mathrm{ft}(30.5 \mathrm{~m})$.

- Frontage. The lot frontage represents the parcel width parallel to the street and directly correlates to the street and sidewalk lengths. The lot frontage in the sketch is $198 \mathrm{ft}(60.5 \mathrm{~m})$. 
- Building area. The allowable building area prescribed in the zoning ordinance directly correlates to the impervious area of the roof.

- Other impervious areas that may be addressed in the zoning ordinance include limits on patios, decking, and garage dimensions and setbacks.

\section{Subdivision Regulations \& Engineering Design Standards}

While zoning ordinances are typically comprehensive in their description of criteria that affects imperviousness, they do not address the specific design details of new development, such as local requirements that govern the design of roads, drainage, utilities and other community services for the development. These details are specified in the appropriate subdivision codes and engineering design standards, which may be developed by local, regional, or state governments and agencies and are intended to complement zoning ordinances and building codes.

\subsubsection{Development Status}

The previous discussion described how the regulation of land use can limit the allowable imperviousness of development. The actual imperviousness of a given parcel may depend on other factors such that zoning can only be used to loosely quantify how the lot actually develops.

The current state of land development or development status of a given parcel of land can range from vacant (i.e. totally undeveloped) to built-out (i.e., fully developed) within its current zoning. For the purposes of this chapter, three status levels have been defined and are described below.

\section{Developed}

This includes all parcels of land considered fully developed within their underlying zoning category. Future development of these is generally not anticipated, with the exception of designated re-development or infill areas.

\section{Developable}

This includes all parcels of land considered potentially developable (or underdeveloped) within their underlying zoning category. In residentially zoned areas, developable parcels can be identified by an existing lot size much larger than allowed under current zoning. For example, a parcel that is 
zoned as 1-acre single family residential with a lot size of 10 acres may be considered developable.

For non-residential areas, developable parcels may be identified by a low ratio of building area to parcel size. For example, if the median ratio of building area to parcel size for an industrially zoned area is 0.20 and one of the parcels only has $1 \%$ building area, it may be considered developable. Although the ratio of building area to parcel size is directly related to imperviousness, it does not account for all types of impervious cover within the parcel. Non-building impervious cover (e.g. parking lots) can be significant in commercial and industrial areas.

\section{Non-Developable}

This includes areas that are zoned as open space as well as those areas that are designated as "protected" lands. Non-developable areas effectively represent the developed state since they can be considered fully developed within their current (open space) zoning.

\subsection{Development Practices}

This section discusses the various practices and constructed facilities for stormwater management, with particular focus on practices that are applicable to new development in large developing watersheds.

For the purposes of this chapter, "development practices" comprise the stormwater management facilities described in this section and the regulatory controls described in the preceding section. While the emphasis is on new development, these practices may also be applied to re-development, infill, and retrofit of existing facilities.

\subsubsection{General Stormwater Management Practices}

Stormwater BMPs collectively refer to the technology and education-based practices that have a direct impact on the release, transport, or discharge of pollutants in municipal stormwater systems. They include maintenance activities, structural controls, and other practices and measures to manage the quantity and improve the quality of stormwater runoff in the most cost effective manner (U.S. Environmental Protection Agency, 2004).

There are many BMPs that can be used to limit or control water quantity and quality impacts. Their effectiveness is highly variable and typically a 
combination of BMPs in a "treatment train" approach is necessary to meet the desired objectives.

Furthermore, the selection of BMPs is site-specific and is a reflection of the unique needs, constraints, and opportunities of individual communities. Other considerations when selecting an appropriate set of BMPs include:

- documented effectiveness at controlling impervious cover or reducing the impact of increased imperviousness;

- long-term reliability achieving the stated reductions;

- capital and operating costs;

- maintenance requirements; and

- other factors affecting the presumed effectiveness of each practice.

There are a variety of on-line resources that offer guidance on these issues, such as http://www.cabmphandbooks.com/. This California Stormwater Quality Association website provides a variety of searchable fact sheets on the selection and implementation of water quantity control and quality treatment practices, particularly those related to new development.

\subsubsection{Development Practice Types}

Development practices have typically been categorized by their form (i.e. structural versus non-structural) or by their location within the stormwater management system.

Non-structural practices refer to stormwater management techniques that represent low-cost institutional, educational, or pollution prevention practices. Such practices include regulatory land use and development controls and are primarily intended to change the activities and behavior of citizens and developers (U.S. Environmental Protection Agency, 2004). Structural practices are engineered facilities that typically serve multiple stormwater management purposes such as minimizing flood and erosion hazards. Environmental protection is further provided by design features that treat runoff water quality through such mechanisms as sedimentation, filtration, sorption, biological uptake and other processes.

Development practices are also categorized by location depending on whether they are at or near the source of runoff generation or further along the stormwater management system. Practices that serve small tributary areas (e.g. less than 5 acres or 2 ha) or which form part of the conveyance system have been referred to as lot level and conveyance controls. Practices that serve larger areas or receive water from a conveyance system have been referred to as end-of-pipe controls (Ontario Min. of the Environment, 2003). 
To better illustrate the principles developed in this chapter, development practices have been classified according to their function in the following three categories:

- water resources preservation or protection measures;

- practices that minimize the amount of impervious cover; and

- practices that minimize the impacts of impervious cover.

\section{Water Resources Preservation/Protection Measures}

Natural watershed functions can be maintained by not allowing development in certain designated areas. Such measures are intended to maintain the flood control, erosion control and water quality treatment functions of natural riparian and wetland areas.

Similar measures can also be applied to existing constructed facilities in the form of regulatory and operational strategies that are intended to maintain the original design capacity of the overall stormwater management system. Together, these protection and prevention measures can safeguard the natural and water resources, infrastructure assets, as well as mitigate flooding and erosion hazards under future land use conditions.

The various types of development practices in this category include:

- Setbacks. Setbacks are regulatory controls intended to protect and maintain natural riparian and wetland functions by maintaining an acceptable buffer between development and the natural or water resource. Riparian setbacks require a minimum distance between buildings or other structures and watercourses. Wetland setbacks require a minimum distance between buildings or other structures and the nearest designated wetland. The key drawbacks are the loss of land to developers, adoption and implementation by communities, and the labor involved in delineating the setbacks.

- Open Space Preservation. Similar to setbacks, the intent is to preserve natural riparian and wetland functions by establishing a continuous "greenspace" corridor. This involves the preservation of large tracts of open space, and may involve acquisition of private lands either by purchase of property or other means (e.g. through conservation easements). In addition to protecting valuable natural and water resources, open space also preserves valuable land for recreational activities and contributes to the overall community character. The key drawbacks are the financial issues related to property acquisition and individual property owner concerns. 
- Maintenance. Maintenance activities and general upkeep of the stormwater management system is intended to allow the components of the system to function at their original design capacity. Activities may include cleaning, debris and vegetation removal, and spot repairs to pipes, culverts, bridges, open channels, facility control structures, catchbasins and inlets, and curb/gutter. Also included are the rehabilitation and renewal activities that replace deteriorating system components.

- Housekeeping Practices. These are operational and administrative practices to manage materials and control illicit connections to the stormwater management system. Activities may include spill prevention and cleanup, household hazardous waste collection, used oil recycling programs, illegal dumping controls, and stormwater inlet stenciling. Illicit connection controls include prevention and detection activities as well as structural measures to improve sanitary sewer and septic tank systems.

\section{Practices that Minimize the Amount of Impervious Cover}

This category includes development practices that are intended to limit the amount of runoff from a site by reducing the amount of impervious cover. By minimizing the amount of runoff, use of these practices can minimize the size and cost of the structural development practices.

These practices are primarily regulatory controls, but may include lot level structural measures. The various development practices types in this category include:

- Imperviousness Restrictions. Limits on the amount of impervious cover can be specified in zoning ordinances, subdivision regulations, and design standards. The key drawbacks are the cost and administration issues of regulatory enforcement.

- Alternative Site Development. This includes site designs that reduce the area of impervious surfaces and/or increase the use of pervious materials. These practices are often tied into aesthetically pleasing amenity features (e.g. traffic-calming measures, low impact development, bike paths and trails). The key drawbacks are that these practices might not comply with safety requirements or other municipal codes (e.g. parking, traffic flow, handicap access). This is particularly a concern in high-density developments, precisely where such practices would have the biggest impact. Maintenance costs for pervious materials can also be an important issue. Examples include: 
- reduced width of paved roadway surfaces, reduced cul-desac sizes and alternative configurations;

- reduced parking space sizes and space requirements, incorporating shared parking, and/or use of pervious paving materials;

- reduced driveway sizes and requirements, incorporating shared driveways, and/or use of pervious paving materials; and

- reduced sidewalk sizes and requirements, limited to one side of the street only, and/or use of pervious materials.

- Impervious Area Disconnection. Where a reduction in impervious cover is not feasible, hydraulically disconnecting the impervious areas (e.g. discharging roof downspouts, parking areas, and sidewalks onto lawns and other landscaped features) often can achieve the same benefit as reducing the impervious cover.

\section{Practices that Minimize the Impact of Impervious Cover}

This category includes structural practices that are intended to provide both flood control and water quality treatment of runoff generated by impervious areas. The various development practices types in this category include:

- Extended Detention. For the purposes of this chapter, extended detention practices represent those facilities designed to capture a water quality storm event volume and discharge it slowly to improve water quality treatment, infiltration capacity, and environmental protection and erosion control. Water quality storm events are the common rainfall events that represent most of annual rainfall in a given area. Water quality storm event volumes in North America range from 0.5-2.5 in (13-64 mm). Examples include dry and wet ponds, bioretention cells, and constructed wetlands. Traditional detention facilities include ponds and reservoirs that store runoff volume designed to provide flood control by reducing peak flows downstream during large, rare events. Extended detention facilities can be integrated with traditional detention facilities to achieve the flood control objectives. The key drawbacks are increased inspection and maintenance requirements, since extended detention practices are designed to trap sediment, debris, and particulates. Depending on the size and location of detention facilities, the cost related to acquisition of property and the regulatory/liability issues related to dam safety are also important considerations. 
- Extended Conveyance. For the purposes of this chapter, extended conveyance practices include wide, low gradient, vegetated areas designed to slow runoff during a water quality storm event, providing traditional conveyance facilities with enhancements to improve water quality treatment through sediment settling and increased filtering by vegetation; infiltration capacity through percolation into the soil; and environmental protection and erosion control through decreased discharge rate and velocity. Examples include vegetated swales, bioretention channels, and filter strips. The key drawbacks are increased inspection and maintenance requirements over closed-conduit and hardened open channel conveyances, as well as limited effectiveness in high-density developments due to space limitations. Traditional conveyance structures include pipes, culverts, and bridges that convey peak runoff rates and are typically designed to drain large, rare storm events and protect structures, property, and roadways from flooding. Extended conveyance structures may be integrated into larger open channels designed to drain large flood events, or may be bypassed by a traditional conveyance structure during events larger than the water quality design storm.

- Infiltration. These include facilities that reduce runoff peaks and volume by promoting infiltration into the soil, either using the natural infiltration capacity of the existing soil or constructed trenches with imported, well-drained materials. Examples include infiltration/ exfiltration trenches and basins, porous pavement, and amended soils. The key drawbacks are very high inspection and maintenance costs. The presence of clay soils and high groundwater levels can also significantly reduce the rate of infiltration resulting in areas of standing water and saturated soils that pose maintenance and vector-breeding problems. In addition to soils considerations, infiltration practices should be avoided in areas near steep or unstable slopes, water supply wells or groundwater recharge areas, structural foundations, and hazardous material storage areas.

\subsection{Case Study}

In this section, a case study in northeast Ohio is used to demonstrate methods for estimating the increase in impervious cover from development 
and for quantifying the resulting impact of various development practices on imperviousness in a large, developing watershed (CDM, 2004).

\subsubsection{Study Description}

The Chagrin River watershed covers an area of 267 square miles $\left(692 \mathrm{~km}^{2}\right)$, representing 40 communities in Cuyahoga, Geauga, Lake, and Portage counties. It is located east of Cleveland, Ohio as shown in Figure 6.3.

The 48-mile $(77 \mathrm{~km})$ main branch of the Chagrin River receives flow from several major tributaries including the East Branch, Griswold Creek, Willey Creek, and the Aurora Branch, discharging north into Lake Erie. Surface waters make up a significant portion of the water resources of the Chagrin River, with over 100 miles $(161 \mathrm{~km})$ of named perennial streams.

Land use changes and practices in the Chagrin River watershed are altering its water and natural resources by disrupting the hydrologic characteristics and ecosystems within the watershed. The principal cause is increased imperviousness due to development (e.g. construction of roads, parking lots, and buildings), removal or alteration of natural vegetation, and other land surface activities occurring on the land.

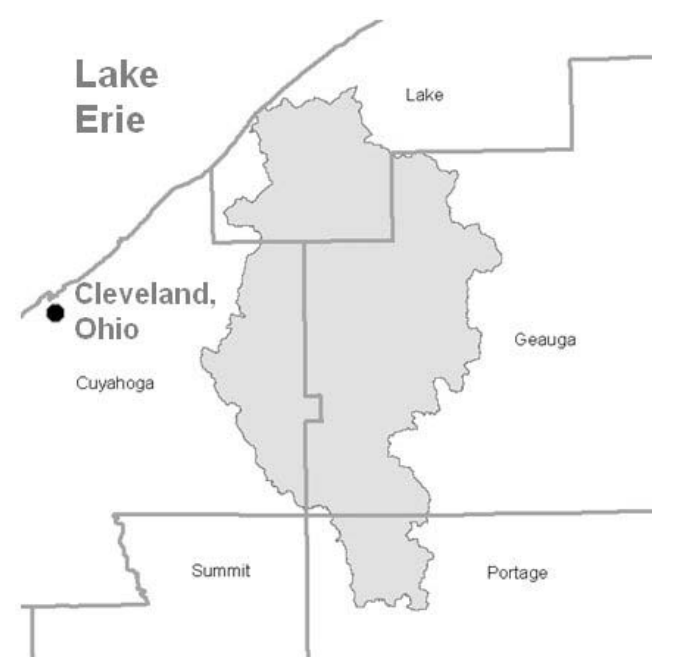

Figure 6.3 Chagrin River watershed in northeast Ohio (showing county boundaries). 
The two main objectives of the study included:

- estimate increases in impervious cover within the watershed from land use changes due to development; and

- qualitatively assess the effectiveness of development practices to control imperviousness or to control the resulting impacts of increased impervious cover.

The challenge in achieving these objectives resulted from the combination of five key factors:

- hydrologic response is typically evaluated on a subcatchment basis;

- land use is regulated at the parcel level;

- the size of the watershed and large number of communities with many different characteristics and available data;

- results must be communicated to non-technical public officials; and

- methods must be flexible enough in order to be adapted and expanded by the individual communities.

The goal therefore, was to relate imperviousness to the zoning and development status of individual parcels and then develop a useful yet easyto-use planning tool capable of evaluating the hydrologic impacts of various development practices on a community by community basis.

\subsubsection{Impervious Cover Analysis}

The impervious cover analysis was intended to establish a link between impervious cover and land use. For the purposes of this study, community zoning codes were grouped into a set of representative land use categories. An estimate of the impervious cover was made for each land use category using available imperviousness estimates and additional measurements.

Representative land use categories were defined that best consolidate the range of imperviousness of the predominant zoning categories for Chagrin River watershed communities. These categories were based on a review of community zoning codes and were generally established at logical breakpoints between typical development patterns and impervious factors. Table 6.1 lists the land use categories developed for this project.

Residential land use categories were generally categorized in terms of the minimum lot size per dwelling unit or the inverse; the number of dwelling units per acre. These ranged from high density (lots less than 0.5 acres, or $0.2 \mathrm{ha}$ ) to low density (lots greater than 2 acres, or $0.8 \mathrm{ha}$ ). Non-residential land use zones were categorized into high density (e.g. retail commercial and industrial land uses) and medium density (e.g. institutional, non-retail 
commercial and light industrial land uses) classes. The non-developable category included areas that were either zoned as open space or were considered protected natural areas.

Table 6.1 Land use categories within the Chagrin River Watershed.

\begin{tabular}{lcccc}
\hline \multicolumn{1}{c}{ Land Use } & \multicolumn{2}{c}{ Minimum Lot Size (ac) } & \multicolumn{2}{c}{ Dwelling Units per Acre } \\
Category & Lower & Upper & Upper & Lower \\
\hline Residential $(<1 / 2$ acre) & $<0.1$ & 0.5 & $>10$ & 2 \\
Residential (1/2 - 1 acre) & 0.5 & 1 & 2 & 1 \\
Residential (1 - 2 acres) & 1 & 2 & 1 & 0.5 \\
Residential ( $>2$ acres) & 2 & $>5$ & 0.5 & $<0.2$ \\
Non-Residential (High) & Categorized by development density (not parcel size) \\
Non-Residential & Categorized by development density (not parcel size) \\
(Medium) & \multicolumn{4}{c}{ Categorized by open-space zoning or "protected" area } \\
Non-Developable & \multicolumn{4}{c}{} \\
\hline
\end{tabular}

Low-density residential zoning was by far the predominant land use within the Chagrin River watershed communities, comprising $43 \%$ of the underlying zoning.

Impervious cover measurements within Chagrin River watershed communities were obtained from both previous available impervious cover measurements and a representative sample of impervious area performed as part of this study by interpreting aerial photographs using GIS procedures. The imperviousness measurements represented a total of 3,382 parcels.

Table 6.2 Imperviousness values within the Chagrin River Watershed.

\begin{tabular}{lrrr}
\hline \multicolumn{1}{c}{ Land Use } & \multicolumn{3}{c}{ Imperviousness } \\
\multicolumn{1}{c}{ Zoning Category } & Low & Average & \multicolumn{1}{c}{ High } \\
\hline Residential (<1/2 acres) & $23 \%$ & $38 \%$ & $53 \%$ \\
Residential (1/2 - 1 acres) & $17 \%$ & $22 \%$ & $27 \%$ \\
Residential (1 - 2 acres) & $8 \%$ & $12 \%$ & $17 \%$ \\
Residential ( $>2$ acres) & $5 \%$ & $9 \%$ & $13 \%$ \\
Non-Residential (High Density) & $43 \%$ & $70 \%$ & $97 \%$ \\
Non-Residential (Medium Density) & $30 \%$ & $59 \%$ & $88 \%$ \\
Non-Developable & $0 \%$ & $2.5 \%$ & $5 \%$ \\
\hline
\end{tabular}


Impervious cover statistics were determined to better quantify the variability and confidence of imperviousness as it correlates to land use characteristics. The representative imperviousness values are summarized in Table 6.2. Given the inherent variability in impervious cover measurements, three categories of imperviousness values were evaluated for the purposes of this study. The average value corresponds to the mean imperviousness value. The low and high values were taken as the average value minus and plus one standard deviation, respectively.

\subsubsection{Land Development Analysis}

The land development analysis identified currently undeveloped land within Chagrin River watershed communities that could be considered potentially developable in the future. The development status levels described previously in section 6.4.3 were used in this study.

Table 6.3 presents the land development analysis results for selected communities. Overall, results indicated $53 \%$ of the area within Chagrin River watershed communities was developable, $34 \%$ was developed, and the remainder (13\%) was considered non-developable. Since it is a highly developable watershed, land use decisions yet to be made within these communities will significantly affect watershed imperviousness.

Table 6.3 Land development status for selected communities.

\begin{tabular}{|c|c|c|c|c|}
\hline \multirow[t]{2}{*}{ Community } & \multicolumn{4}{|c|}{ Land Use Zoning Percentages } \\
\hline & Developable & Developed & $\begin{array}{c}\text { Non- } \\
\text { Developable }\end{array}$ & Total \\
\hline Auburn Township & $62.6 \%$ & $16.4 \%$ & $21.0 \%$ & $100.0 \%$ \\
\hline Bainbridge Township & $53.4 \%$ & $38.3 \%$ & $8.4 \%$ & $100.0 \%$ \\
\hline City of Chardon & $43.1 \%$ & $36.8 \%$ & $20.1 \%$ & $100.0 \%$ \\
\hline Chardon Township & $56.7 \%$ & $22.7 \%$ & $20.5 \%$ & $100.0 \%$ \\
\hline Chester Township & $47.0 \%$ & $50.0 \%$ & $3.0 \%$ & $100.0 \%$ \\
\hline City of Kirtland & $52.1 \%$ & $23.3 \%$ & $24.6 \%$ & $100.0 \%$ \\
\hline Munson Township & $46.8 \%$ & $35.2 \%$ & $18.0 \%$ & $100.0 \%$ \\
\hline Newbury Township & $70.9 \%$ & $18.3 \%$ & $10.8 \%$ & $100.0 \%$ \\
\hline Russell Township & $47.3 \%$ & $39.3 \%$ & $13.4 \%$ & $100.0 \%$ \\
\hline South Russell Village & $44.4 \%$ & $54.2 \%$ & $1.4 \%$ & $100.0 \%$ \\
\hline
\end{tabular}




\subsubsection{Development Practices Evaluated}

Of the development practice types described previously in section 6.5.2, only those practices that minimized the amount of impervious cover or the impacts of imperviousness were evaluated. Although the preservation and protection measures were not explicitly evaluated, they do provide maintenance of existing stormwater management functions and water quality treatment. These should be considered at the onset of site design.

The specific scenarios that were evaluated for this study include:

1. Existing Conditions, representing the current development status.

2. Build-out Conditions. This scenario represents uncontrolled development according to current zoning.

3. Upzoning. This scenario represents build-out development where zoning is allowed to increase from low-density to high-density residential, commonly referred to as "upzoning". Rather than showing the positive impact of zoning restrictions, this scenario was meant to show the negative impact of a common zoning practice.

4. Impervious Cover Reduction. This scenario represents build-out development using alternative site designs in which impervious cover is reduced by $5 \%$ compared to uncontrolled development.

5. Extended Detention. This scenario represents build-out development with extended detention facilities.

6. Extended Conveyance. This represents build-out development with extended conveyance such as vegetated swales or filter strips.

Infiltration practices were not evaluated as they are generally not feasible due to predominately poorly drained soils within the watershed.

\subsubsection{Hydrologic and Hydraulic Methods}

To meet the objectives of this study, the impact of development practices on watershed hydrology and hydraulics was evaluated in terms of peak runoff rates and volumes on a unit area basis. As a result, a rational method approach (i.e. a simple linear relationship between rainfall and runoff) was used.

Despite its shortcomings, the rational method is still a useful tool for such planning level applications as this. It served as an educational tool to illustrate basic hydrologic and hydraulic concepts, allowing for easier communication of results to a non-technical audience. Computer models that more accurately simulate hydrologic and hydraulic routing (e.g. HEC-HMS 
and HEC-RAS for steady state simulations, SWMM for dynamic simulations) are appropriate for a more detailed evaluation on a community or sub-watershed basis. More detailed modeling methods for representing development practices are described in Myers et al., 2004.

To apply the methodology, a linear relationship between the runoff coefficient and imperviousness was defined according to Equation 6.2. For example, $0 \%$ imperviousness represents a runoff coefficient of 0.2 and $100 \%$ imperviousness represents a runoff coefficient of 0.8 .

where:

$$
C=0.6 I+0.2
$$

$$
\begin{aligned}
\mathrm{C} & =\text { the coefficient of runoff; and } \\
\mathrm{I} & =\text { the total impervious area. }
\end{aligned}
$$

This equation has a simpler form than the 3rd order polynomial equation described by Equation 6.3 (WEF/ASCE, 1998). The linear relationship in Equation 6.2 agrees with detailed modeling results obtained as part of the Regional Intercommunity Drainage Evaluation conducted in the greater Cleveland area (Gregory et al., 2005).

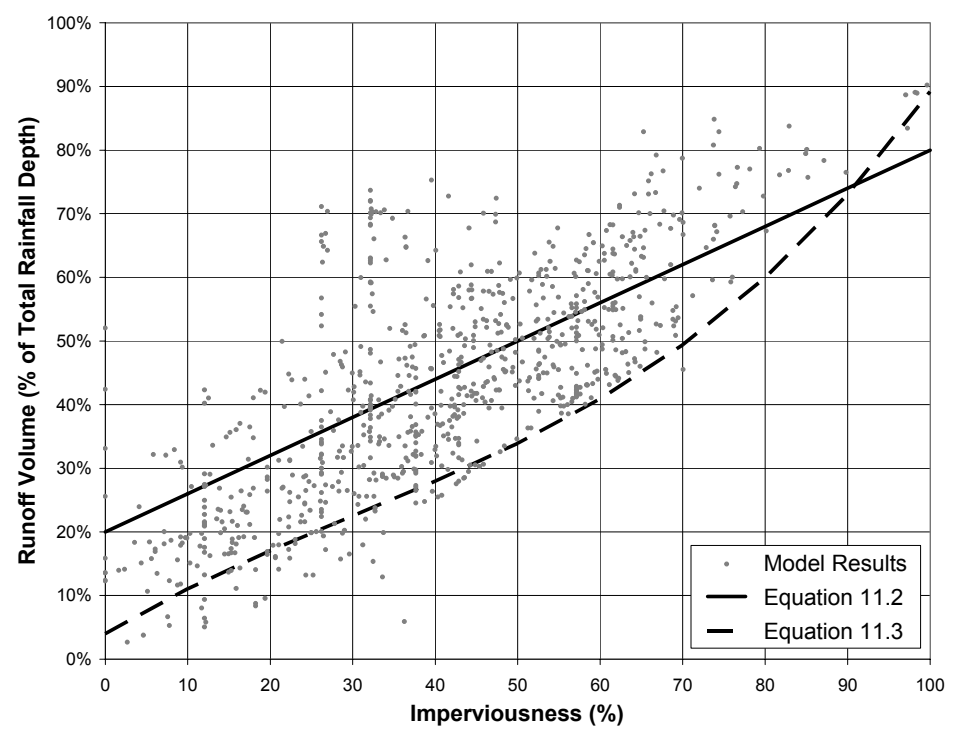

Figure 6.4 Runoff response for 855 subcatchments in Cleveland, $\mathrm{OH}$. 
Figure 6.4 compares Equations 6.2 and 6.3 with the computed runoff coefficient (i.e. the runoff volume expressed as a percentage of the total rainfall depth) for 855 subcatchments for a local $2 \mathrm{y} / 24 \mathrm{~h}$ design storm event.

$$
C=0.858 I^{3}-0.78 I^{2}+0.774 I+0.04
$$

where I and $\mathrm{C}$ have the same definitions as shown in Equation 6.2.

Since the emphasis of this study was to evaluate the impacts on hydrology related to environmental protection (i.e. water quality and stream stability), the statistics associated with frequent rainfall events were evaluated to determine the local water quality design storm event. The water quality event used in this study represents a rainfall depth of 0.75 in $(19 \mathrm{~mm})$ over $24 \mathrm{~h}$ with a peak hourly intensity of $0.55 \mathrm{in} / \mathrm{h}(14 \mathrm{~mm} / \mathrm{h})$.

\subsubsection{Analysis Results and Discussion}

The imperviousness impact analysis was performed on the six development scenarios listed above. Scenarios were grouped into the following categories:

- baseline conditions, representing the Existing Conditions and BuildOut Conditions scenarios;

- practices that minimize the amount of impervious cover, which includes the Upzoning and Impervious Cover Reduction scenarios;

- practices that minimize the impacts of impervious cover, which includes the Extended Detention and Extended Conveyance scenarios.

\section{Baseline Conditions}

The Existing and Build-Out Conditions scenarios represent the baseline conditions (i.e. without development practices) to which the other scenarios were compared. A set of hydrologic and hydraulic parameters was developed for a representative 1-acre unit area for each land use category.

For example, a typical 1-acre residential lot like the example shown in Figure 6.2 was assigned an estimated overland flow path length of $100 \mathrm{ft}$. The overland flow path length was adjusted for other land use categories depending on the development density (i.e. a shorter length for more dense development, longer for less dense development). 
According to the rational method, an estimate of the overland flow path length and slope were used to determine the catchment time of concentration, which was then used to determine the appropriate rainfall depth and intensity of the water quality design storm event. In this manner, a range of runoff rates and volumes was calculated for each of the land use categories and ranges of imperviousness values (i.e. low, average, and high) as shown in Table 6.2. Under existing conditions, developable land was assigned the same imperviousness and hydrology parameters as nondevelopable open space.

Table 6.4 shows the existing conditions results for imperviousness, peak runoff rate and runoff volume for selected communities. Runoff results are shown for the water quality event described earlier and are reported on a unit area basis: runoff rate is expressed as cubic feet per second per acre (cfs/ac); and runoff volume as acre-feet per acre (ac-ft/ac).

For all 40 Chagrin River watershed communities, the average imperviousness value was $8.1 \%$ under existing development conditions. This value is characteristic of an un-urbanized watershed, based on numerous watershed studies throughout the U.S. Only one of the communities had an average imperviousness value greater than $25 \%$, the upper threshold where it has been suggested that ecological indicators are poorest as discussed in section 6.3.4.

Table 6.4 Existing condition results for selected communities.

\begin{tabular}{rrrrrrrrrr}
\hline \multicolumn{4}{c}{ Imperviousness (\%) } & \multicolumn{9}{c}{ Water Quality Event } \\
\multicolumn{1}{c}{} & \multicolumn{1}{c}{ Peak Runoff Rate (cfs/ac) } & \multicolumn{2}{c}{ Runoff Volume (ac-ft/ac) } \\
& \multicolumn{1}{c}{ Low } & \multicolumn{1}{c}{ High } & \multicolumn{1}{c}{ Low } & \multicolumn{1}{c}{ Avg. } & High & Low & Avg. & High \\
\hline 1 & $1.5 \%$ & $4.6 \%$ & $7.6 \%$ & 0.22 & 0.24 & 0.27 & 0.013 & 0.014 & 0.015 \\
2 & $2.3 \%$ & $5.6 \%$ & $9.0 \%$ & 0.22 & 0.25 & 0.28 & 0.013 & 0.015 & 0.016 \\
3 & $6.1 \%$ & $12.4 \%$ & $18.6 \%$ & 0.27 & 0.33 & 0.41 & 0.015 & 0.017 & 0.019 \\
4 & $1.8 \%$ & $4.8 \%$ & $7.9 \%$ & 0.22 & 0.25 & 0.27 & 0.013 & 0.014 & 0.015 \\
5 & $3.8 \%$ & $7.6 \%$ & $11.5 \%$ & 0.24 & 0.27 & 0.31 & 0.014 & 0.015 & 0.017 \\
6 & $3.3 \%$ & $6.8 \%$ & $10.3 \%$ & 0.24 & 0.27 & 0.31 & 0.014 & 0.015 & 0.016 \\
7 & $3.2 \%$ & $7.6 \%$ & $12.0 \%$ & 0.23 & 0.27 & 0.32 & 0.014 & 0.015 & 0.017 \\
8 & $1.2 \%$ & $4.2 \%$ & $7.2 \%$ & 0.22 & 0.24 & 0.26 & 0.013 & 0.014 & 0.015 \\
9 & $2.0 \%$ & $5.1 \%$ & $8.2 \%$ & 0.22 & 0.24 & 0.27 & 0.013 & 0.014 & 0.016 \\
10 & $8.9 \%$ & $13.4 \%$ & $17.9 \%$ & 0.32 & 0.36 & 0.41 & 0.016 & 0.018 & 0.019 \\
\hline
\end{tabular}

Community: 1 Auburn Township, 2 Bainbridge Township, 3 City of Chardon,

4 Chardon Township, 5 Chester Township, 6 City of Kirtland, 7 Munson Township, 8

Newbury Township, 9 Russell Township, 10 South Russell Village 
To represent future build-out conditions, developable land was assigned the appropriate imperviousness and hydrology parameters for the corresponding underlying land use category. For all Chagrin River watershed communities, the average imperviousness value was $17.5 \%$ under build-out conditions. This represents a $9.4 \%$ increase compared to existing conditions and is characteristic of urbanized watersheds. Twelve communities indicated an average imperviousness value greater than $25 \%$. The average runoff rate increased by $36 \%$ and the average runoff volume increased by $23 \%$ compared to existing conditions.

Future build-out conditions represent uncontrolled development (i.e., build-out under existing zoning without development practices). Results for this scenario were used as the baseline to which all subsequent development practices were compared and evaluated.

\section{Practices that Minimize the Amount of Impervious Cover}

The first scenario evaluated for this type of development practice presents an example of the impact of rezoning all developable low-density residential ( $>2$-acre lots) parcels to a medium-density residential ( $1 / 2-$ to 1 -acre lots) category under build-out conditions. This scenario was meant to demonstrate the negative impact of increasing the amount of impervious cover.

For all Chagrin River watershed communities, the average imperviousness value was $20.9 \%$ for Chagrin River watershed communities under the upzoning scenario. This is a $3.4 \%$ increase compared to build-out conditions. Thirteen communities indicated an average imperviousness value greater than $25 \%$. The overall average runoff rate increased by $13 \%$ and the average runoff volume increased by $7 \%$ compared to build-out conditions.

The second scenario evaluated for development practices that minimize impervious cover presents an example of alternative site development. The scenario characterizes development practices that achieve a 5\% reduction in impervious cover across all developable land use categories, and can represent a combination of practices such as reduced street widths and parking space requirements.

The reduced imperviousness values were applied to all developable areas within Chagrin River watershed communities. Existing imperviousness values were used in non-developable areas. Additionally, this scenario also applied the reduced imperviousness values to a portion of the developed non-residential areas, representing a redevelopment scenario. For this study, a $20 \%$ redevelopment factor was used. 
For all Chagrin River watershed communities, the average imperviousness value was $14.9 \%$ under the impervious cover reduction scenario. This development practice demonstrates a beneficial impact, reducing the average imperviousness by $2.7 \%$ compared to uncontrolled build-out conditions. Similarly, the average runoff rate and runoff volume decreased by $6 \%$ and $5 \%$, respectively, compared to uncontrolled build-out conditions.

\section{Practices that Minimize the Impacts of Impervious Cover}

The first scenario evaluated for this type of development practice presents an example of extended detention that achieves the requirement of treating the post-construction water quality volume in developable areas. By limiting the release of the runoff volume from the water quality storm event over a period of 24 hours, the peak unit runoff rate is greatly reduced compared to uncontrolled detention. Imperviousness and runoff volume are unaffected.

For all Chagrin River watershed communities, the average imperviousness value was $17.5 \%$ for the extended detention scenario. As mentioned earlier, this development practice is not intended to reduce impervious cover and therefore does not change the average imperviousness compared to uncontrolled build-out conditions. Similarly, the average runoff volume is unchanged compared to uncontrolled build-out conditions. The benefit of extended detention is indicated by a greatly reduced average peak runoff rate. The average runoff rate is decreased by $57 \%$ for Chagrin River watershed communities under the extended detention scenario.

The second scenario evaluated for development practices that minimize impervious cover impacts presents an example of extended conveyance facilities such as swales and filter strips. These facilities were represented by increasing the flow path length and decreasing the flow path slope. It was felt that doubling the flow path length and halving the slope were within practical limits and representative of typical grading practices that must be steep enough to support lot drainage yet not too flat so as to be inundated for excessive periods.

To better quantify runoff, the runoff volume was separated into impervious and pervious components. It is the impervious portion of runoff that is "treated" (i.e. removed by infiltration) by extended conveyance facilities. A treatment rate of $0.25 \mathrm{in} / \mathrm{h}(6 \mathrm{~mm} / \mathrm{h})$ was used, representative of the typical clayey soils found throughout the watershed. This treatment rate was applied over the surface area covered by an extended conveyance facility, which is typically $5 \%$ of the total lot area. The treatment time 
represents the time taken to infiltrate the entire impervious portion of runoff volume, if all the impervious runoff could be detained in the facility. Since extended conveyance systems have a typical residence or "flow through" time on the order of two hours, the ratio of $2 \mathrm{~h}$ over the calculated full treatment time was applied to the impervious runoff volume to determine the actual runoff volume infiltrated by the facility.

For all Chagrin River watershed communities, the average imperviousness value was $17.5 \%$ for the extended conveyance scenario. As mentioned earlier, this development practice is not intended to reduce impervious cover and therefore does not change the average imperviousness compared to uncontrolled build-out conditions. The average runoff rate decreased by $16 \%$ and the average runoff volume decreased by $6 \%$ for Chagrin River watershed communities under the extended conveyance scenario (i.e., for conveyance facilities in all developable residential areas and designated non-residential re-development areas under build-out conditions).

Although riparian setbacks were not explicitly evaluated as a development practice in this study, they can enhance the effectiveness of extended conveyance practices. This analysis considered poorly-drained soils as a limiting factor on the infiltration of runoff. Riparian setbacks are often located in floodplain areas where soils are better drained, resulting in extended conveyance facilities with higher infiltration capacity, and therefore greater runoff volume reduction. Similarly, wetland setbacks and wetlands will also act as detention facilities.

\subsubsection{Case Study Conclusions}

The Chagrin River watershed is partially undeveloped at present, yet still experiences flooding, erosion, and water quality problems. Given the tremendous potential for development and redevelopment, it is critical that communities understand the impact of development on flooding, erosion, and attainment of water quality standards.

The imperviousness impact analysis of the various development practices that were evaluated in this case study is summarized in Table 6.5. The average runoff rates and volumes are compared to the uncontrolled future build-out conditions.

This study further emphasizes the importance of adopting appropriate regulations and policies to implement recommendations. There is no single practice that can achieve all watershed and stormwater management objectives or that is equally applicable to all communities in the Chagrin 
River watershed. It is the combination of zoning regulations, planning and BMPs that offer the most effective strategy for dealing with the increased stormwater runoff rate and volume due to development.

Table 6.5 Imperviousness impact analysis summary.

\begin{tabular}{lrrr}
\hline \multicolumn{1}{c}{$\begin{array}{c}\text { Scenario } \\
\text { Evaluated }\end{array}$} & $\begin{array}{c}\text { Average } \\
\text { Imperviousness } \\
\text { Value }\end{array}$ & $\begin{array}{c}\text { Average } \\
\text { Runoff Rate } \\
\text { (Difference) }\end{array}$ & $\begin{array}{c}\text { Average Runoff } \\
\text { Volume } \\
\text { (Difference) }\end{array}$ \\
\hline Existing Conditions & $8.1 \%$ & $-36 \%$ & $-23 \%$ \\
Build-out Conditions & $17.5 \%$ & $0 \%$ & $0 \%$ \\
Upzoning & $20.9 \%$ & $+13 \%$ & $+7 \%$ \\
Impervious Cover Reduction & $14.9 \%$ & $-6 \%$ & $-5 \%$ \\
Extended Detention & $17.5 \%$ & $-57 \%$ & $0 \%$ \\
Extended Conveyance & $17.5 \%$ & $-16 \%$ & $-6 \%$ \\
\hline
\end{tabular}

Conclusions based on the study findings are summarized below.

\section{Water Resources Preservation/Protection Measures}

- Riparian and Wetland Setbacks. The primary purpose of these setbacks is to maintain functions of existing streams, wetlands and floodplains. While not explicitly evaluated in this study, setbacks may also provide a secondary purpose of improving the effectiveness of other development practices, such as extended conveyance facilities. In addition, riparian setbacks may encompass floodplain areas, which typically have better draining soils than are generally found throughout the Chagrin River watershed. As a result, extended conveyance provided by these setback areas can achieve higher runoff volume reductions than those placed within re-graded, compacted and/or landscaped potions of a development site.

- Open Space Preservation. While 13\% of the Chagrin River watershed communities are in protected open space, only $1 \%$ of that area is zoned as open space. The analysis also showed that several communities have little or no protected open space. Communities should analyze the existing amount of protected open space to determine if the amount and location of the open space is commensurate with local comprehensive plans. In addition, targeted open space acquisition or conservation easement acquisition may 
also be able to assist communities to address concerns related to underdeveloped properties.

Practices that Minimize the Amount of Impervious Cover

- Zoning Restrictions. The impact of rezoning from low-density residential to higher density residential was demonstrated for the "upzoning" scenario, which would have offset the benefits achieved by the extended conveyance scenario, for example. These results verify the negative impacts of higher density residential zoning and lend further support to large lot zoning and low overall densities. The implementation of zoning restrictions would require the use of appropriate zoning policy tools to control and regulate the amount of impervious cover. A number of communities have already adopted lot level limits on impervious cover.

- Impervious Cover Reductions. Reductions in imperviousness, whether through zoning restrictions or through alternative site designs, reduce runoff generated by development practices. In some cases, the rate and volume reduction is proportional to the reduction in imperviousness.

\section{Practices that Minimize the Impact of Impervious Cover}

- Extended Detention. These facilities are very effective at removing pollutants and preventing erosive flows in streams because they reduce post-development runoff peaks during the water quality event to less than pre-development runoff peaks to compensate for increased runoff volumes. Although having no impact on imperviousness or the average watershed runoff volume, tremendous reductions in runoff rates can be achieved. While the use of extended detention is typically limited to larger facilities serving more than 10 acres (4.0 ha.), they can be integrated into a decentralized stormwater management system if outlets are provided that resist clogging (e.g. a bio-retention basin with an underdrain and amended soils to promote drainage).

- Extended Conveyance. These facilities are effective at removing pollutants and reducing runoff peaks and volumes, except during periods of soil saturation and limited infiltration capacity and evapotranspiration. Although having no impact on imperviousness, the extended conveyance scenario evaluated in this study showed significant reductions in the runoff rates and volumes. Since runoff 
"flows through" these facilities, they can be designed to reduce the aesthetic, saturated soil, and vector breeding issues associated with infiltration practices that do not release runoff to surface waters.

- Operation and Maintenance Requirements. All constructed facilities, from large-scale regional detention ponds to small-scale decentralized controls, must be appropriately sited, designed, and maintained. Water quantity and quality benefits cannot be achieved if facilities are located in an inappropriate site (e.g. a facility that relies upon infiltration of runoff into clayey soils), poorly designed, or poorly maintained. Government regulatory controls will always be required, and the level of regulation and enforcement necessary to provide the proper operation of these facilities must be determined prior to implementation.

\subsection{Conclusions and Recommendations}

An evaluation of the effectiveness of development practices must be sufficient to support engineers and planners in their designs and site plans as well as zoning and policy tools to control impervious cover. Such an evaluation can be a labor-intensive and time-consuming exercise within large watersheds when using advanced computer models and analysis methods. As a result, there is a need for simplified, planning-level methods that can be applied at a watershed or community scale that are easy to use and apply as well as to educate and communicate results.

The methodologies presented in this chapter demonstrate how impervious cover can be evaluated in large watersheds under a variety of development scenarios. The case study also emphasizes the importance of adopting appropriate regulations and implementation policies in combination with structural facilities to deal with increased runoff due to development.

Imperviousness is an indicator of adverse environmental impacts, yet it is measurable and can be managed and controlled through land use policies and design standards. By understanding the impact of potential land use changes on the flooding, erosion, and water quality problems of the watershed, planning officials can make informed land use planning and management decisions.

Limiting the amount and impact of impervious cover can be achieved through a combination of the following activities:

- comprehensive planning; 
- $\quad$ targeted open space acquisition;

- $\quad$ riparian and wetland setbacks;

- $\quad$ alternative site designs to maintain overall low density; and

- good stormwater management.

The recommendations for future evaluations include:

- Extending the level of analysis detail within individual communities, which would involve the use of more sophisticated hydrologic and hydraulic models at a subwatershed scale;

- Targeting more specific zoning regulations, design standards, and development practices than the scenarios evaluated in the case study; and

- Investigating impacts on stream stability; sediment, pollutant, and temperature loading; and on more direct measures of aquatic and terrestrial ecosystems.

\section{References}

Alley, W.M. and J.E. Veenhuis (1983). Effective Impervious Area in Urban Runoff Modeling. Journal of Hydraulic Engineering, Vol. 109 (2); pages 313-319.

Arnold, C. and J. Gibbons (1996). Impervious Surface Coverage: The Emergence of a Key Environmental Indicator. Journal of the American Planning Association, Vol. 62 (2); pages 243-258.

CDM Inc. (2004). Chagrin River Watershed Impervious Area Study, Final Report.

Gibbons, J. (1998). Addressing Imperviousness in Plans, Site Design and Land Use Regulations. Technical Paper No. 1; University of Connecticut, Nonpoint Education for Municipal Officials.

Gregory, M., J. Aldrich, M.F. Schmidt, J.E. Duke and B. Barker. 2005. "Development and Evaluation of Stormwater Improvement Alternatives." Journal of Water Management Modeling R223-01. doi: 10.14796/JWMM.R223-01.

Lee, J.G. and J.P. Heaney (2003). Estimation of Urban Imperviousness and its Impacts on Storm Water Systems. Journal of Water Resources Planning and Management, Vol. 129 (5); pages 419-426.

Myers, D., M. Maimone, J. Smullen and B.G. Marengo. 2004. "Simulation of Urban Wet Weather Best Management Practices at the Watershed Scale." Journal of Water Management Modeling R220-12. doi: 10.14796/JWMM.R220-12.

Ontario Ministry of the Environment (2003). Stormwater Management Planning and Design Manual. Publication 4329e, ISBN 0-7794-2969-9.

Rosenfeld, A.H., J.J. Romm, H. Akbari, and A.C. Lloyd (1997). Paint the Town Whiteand Green. MIT Technology Review, Feb/Mar 1997.

Schueler, T. (2003). Impacts of Impervious Cover on Aquatic Systems. Center for Watershed Protection; Ellicott City, MD 
Stocker, J. (1998). Methods for Measuring and Estimating Impervious Surface Coverage. Technical Paper No. 3; University of Connecticut, Nonpoint Education for Municipal Officials.

Stone, B. (2004). Paving Over Paradise: How Land Use Regulations Promote Residential Imperviousness. Journal of Landscape and Urban Planning, Vol. 69; pages 101-113.

U.S. Environmental Protection Agency (1997). Urbanization and Streams: Studies of Hydrologic Impacts. Office of Water; Publication 841-R-97-009; Washington, DC.

U.S. Environmental Protection Agency (2004). The Use of Best Management Practices (BMPs) in Urban Watersheds. Office of Research and Development; Publication 600-R-04-184; Washington, DC.

WEF (Water Environment Federation) and ASCE (American Society of Civil Engineers) (1998). Urban Runoff Quality Management, WEF Manual of Practice No. 23/ASCE Manual and Report of Engineering Practice No. 87. 